\title{
CHARACTERIZATION OF CROP/LIVESTOCK PRODUCTION SYSTEM IN RECLAIMED AREAS OF EGYPT
}

\author{
Y.A. Abdel-Aziz \\ Animal Production Research Institute, Cairo, Egypt \\ Email: yaaa21064@yahoo.ca
}

\section{SUMMARY}

The current study used system approach to characterize the existing crop/livestock production system in the reclaimed areas to assess its economical efficiency in four governorates. The four governorates were; Behira, North Sinai, Fayoum and Menia. A random sample of 151 farms were investigated. A questionnaire was designed to cover available resources, farming activities, variable costs and revenues. Least squares analysis of variance technique was performed to derive technical coefficients for livestock and major crops production performance. Gross margin per animal unit and per feddan was estimated as a measure of economical efficiency. The overall means of family size, farm size and herd size were estimated as 5.2 person, 3.9 feddan, 1.8 head, respectively. Buffaloes and cows raised in Fayoum produced more total milk yield (2492 and $1688 \mathrm{~kg}$, respectively) compared to those of the other governorates. Results showed that wheat is the main winter cash crop and maize is considered the major summer cash crop in Behira, Fayoum and Menia. In North Sinai farmers are interested in cultivating $50 \%$ of the farm size with olive and $44 \%$ with peach. Behira beneficiaries utilized their limited production resources more efficient than the other studied governorates since they achieved the highest return per feddan and per animal unit (AU) among the studied areas (LE 7276 and 11520, respectively).

Keywords: system approach, crop/livestock, reclaimed areas, gross margin, Egypt

\section{INTRODUCTION}

Mixed farming system including both livestock and crop components represents the dominant type of farming in Egypt. Interactions between those components often have major impact on the productivity and economical efficiency of the current farming system. In general, most farmers in the reclaimed lands, as in old lands, use simple technology in farming. The production of small scale mixed farms is still low and have to be raised to adequate standards to generate satisfactory income. This could be achieved through improving the efficiency of the whole system and providing farmers with appropriate technologies to improve the utilization of their limited production resources. The adoption of such technologies should be based on findings of the characterization of the existing system.

Considerable agreement exists among research workers regarding the general framework required for farming systems research (Zanddstra, 1977; Byerlee et al. 1980; and Nygaard, 1980). Most of authors considered a careful description of the existing farming system as an important first step to understand how the current system works. Robert (1982) stated that results of the characterization phase should provide sufficient understanding for development of hypotheses about production constraints. Farm budget is concerned with organizing production resources on a farm to maximize profits, more often, family satisfaction. Preparation of farm budget allows planning for efficient use of resources and reflects the profitability of a farming system on an annual basis. Whole farm budget was adopted as a tool for financial evaluation of the current farming system.
In Egypt, about $96 \%$ of cattle and buffalo populations are raised under crop/livestock production system and produce about $70 \%$ of the total domestic milk production (Abdel-Salam et al. 2008). Therefore, the current study followed a system approach as described by Morely (1982) to; 1) characterize the existing mixed farming system, 2) estimate the technical coefficients of both livestock and crop components, and 3) calculate farm budget to asses the economical efficiency of the system. Such a study would be useful in planning for comprehensive improvement of the mixed farming system in Behira, North Sinai, Fayoum and Menia governorates.

\section{MATERIALS AND METHODS}

\section{The study areas}

Four governorates with respect to major farming schemes were identified to be the areas of the study. These four governorates were; Behira located at West of Nile Delta, North Sinai located at Eastern-North of Egypt, Fayoum located at the middle of Egypt and Menia governorate located at upper Egypt. These four areas contain variety of small scale mixed farming system of different farm size and cropping pattern. All beneficiaries operate mixed farming system where animal and crop activities are practiced.

\section{Data collection}

A random sample of 151 farms was investigated. The sample represented about $10 \%$ of the farmers enrolled in Central Fund of Animal Wealth Development (CFAWD), Ministry of Agriculture and Land Reclamation (MALR). The distribution of the 
selected farms among the studied governorates were as follows; 30 farms from Behira governorate, located at two villages, 39 farms from North Sinai governorate located at two villages, 30 farms from Fayoum governorate located at two villages and 52 farms from Menia governorate, located at three villages. A questionnaire was designed to cover available resources, farming activities, variable costs and revenues.

A field survey was performed and data were collected over one agricultural year (2013/2014). Data included the following variables: 1) production resources; namely farm size, family size and herd composition, 2) animal production performance; daily milk yield (DMY) in $\mathrm{kg}$, lactation period (LP) in days, total milk yield (TMY) in $\mathrm{kg}$ and calving interval (CI) in days, 3) crop production performance per feddan; main crop yield and by-product yield, and 4) farm budget; variable costs, which included feeding hired labor, veterinary services, fertilizers, seeds and machineries power in addition to revenues generated from animal and crop activities.

\section{Statistical analysis}

Least squares analysis of variance technique using the General Linear Model Procedure of SAS (2001) was performed to investigate the differences in production resources, livestock and crop performance among the studied governorates and to derive technical coefficients for livestock and major crops production performance. Data were analyzed using the following statistical model:

$$
Y_{\mathrm{ij}}=\mathrm{u}+\mathrm{a}_{\mathrm{i}}+\mathrm{e}_{\mathrm{ij}}
$$

Where $Y_{\mathrm{ij}}$ is the observation of crop or animal production, $\mathrm{u}$ is the general mean, a common element to all observations in the sample, $a_{\mathrm{i}}$ is the effect due to the $\mathrm{i}^{\text {th }}$ governorate, $i=1,2,3,4$ (1=Behira, 2= North Sinai, 3=Fayoum and $4=$ Menia), $\mathrm{e}_{\mathrm{ij}}$ is a random effect associated with the individual observation. This element represents all the unidentified factors that may affect the traits under investigation and are not included in the model.

\section{Farm budget}

The value of production was measured in terms of total gross output. This measure combines many different farm products into one measure. Gross output was calculated by multiplying the total quantities of the final marketable product by its current farm gate price, as the farm gate represents the point of first sale, while the variable costs for different input items were calculated by multiplying the quantities of its inputs needed by its current market price. Barnard and Nix (1993) defined whole gross margin of an enterprise as its gross output less variable costs attributed to it.

\section{Economical efficiency}

To facilitate economical comparison among farms of different production resources, farm size and field activities, economical efficiency of the studied mixed farming system, return per unit of the limiting production resources was calculated by dividing the whole gross margin of the farm by the number of resource units needed. Gross margin per animal unit and per feddan was estimated as measure of economical efficiency among the four studied governorates.

\section{RESULTS AND DISCUSSION}

\section{Common features of the current mixed farming system}

Results of the field survey derived from the questionnaire showed that mixed farming system is the dominating system and is practiced in a small farm size, where about third of the cultivated area is allocated for green fodder production. The remaining area is allocated to other cash crops. Most farmers own a small-scale number of cows and/or buffaloes, sheep, goats and poultry are also raised on some farms.

Concerning livestock activities, under the current mixed farming system in the studied governorates, three types of herds were identified according to the composition of herds: cow-herds, buffalo-herds and mixed-herds which include both cows and buffaloes. The distribution of these herds is given in Table (1). The farmers purchased their animals either from the village market or from CFAWD. Replacement heifers that are raised on the farm represent a third source. The cattle breeds raised in the studied areas are native breeds and crossbreds. In addition, farmers used to grow few numbers of small ruminants and poultry. Animals are kept in small enclosures connected to the family house.

Table 1. Type of herds in the four studied areas

\begin{tabular}{lcccc}
\hline \multirow{2}{*}{ Type of herds } & \multicolumn{4}{c}{ Governorates } \\
\cline { 2 - 5 } & Behira & North Sinai & Fayoum & Menia \\
\hline Cow only herds $(\%)$ & 73 & 100 & 10 & 50 \\
Buffalo only herds $(\%)$ & 20 & ---- & --- \\
Mixed herds (\%) & 7 & --- & 90 & 50 \\
Total & 100 & 100 & 100 & 100 \\
\hline
\end{tabular}

The cropping pattern resulted from the interaction of farmers' objectives, natural factors, government policy, managerial capabilities and financial capacities. Allocation of land for various crops was left to the farmer decision. Results of the field survey for the major field crops in cultivated areas are shown in Table
(2). Results showed that considerable proportion of the farm size is allocated to produce fodder crops, especially in winter $(28 \%-51 \%)$. On the other hand, wheat is clearly the main winter cash crop in the studied governorates, Behira, Fayoum and Menia, representing $48 \%, 28 \%$ and $47 \%$ of the total farm size, 
respectively. In North Sinai, farmers are cultivating $50 \%$ of the farm size with olive and $44 \%$ of the farm size with peach, this may be due to climatic conditions, type of soil and shortage of irrigation water. In addition, field survey results revealed that maize crop is considered the major summer cash crop in Behira, Fayoum and Menia governorates representing 47\%, $30 \%$ and $39 \%$, respectively, of the farm size.

The least squares means $(\overline{\boldsymbol{X}})$ and standard errors (SE) for the available production resources are presented in Table (3). The overall means of family size, farm size and herd size were estimated as 5.2 person, 3.8 feddan, 1.8 heads, respectively. Behira governorate has the smallest farm size (1.9 feddan), while North Sinai has the largest one (6.1 feddan). Fayoum and Menia governorates have the largest herd size (2.8 and 2.1, respectively) compared to the other two governorate.

\section{Animal management practices}

Animals are taken care of by family labour, mainly women. In most cases, cows and buffaloes are served naturally with bulls available in the village. Mating is arranged in such a way that cows and buffaloes would calve within the clover season (October-May). Egyptian clover (Trifolium alexandrinum) is the main source of feeding in winter. While in summer, animals are fed on fodder maize (darawa), rice straw and crops by-product, in addition to some concentrates purchased from the market. Animals are hand milked twice a day, and some of the produced milk go to family consumption either fresh or in the form of processed milk (cottage cheese, butter and ghee). Surplus fresh milk and/or milk products are sold at the village market or to middle-man. Results of milk chain and distribution in the studied governorates showed that most of the farmers marketed milk, either fresh or in the form of processed milk (cottage cheese, butter and ghee), about $70 \%$ of produced milk to the intermediaries or direct in the village market, while family consumed only about one third or less of the whole produced milk (buffalo and cow milk) as presented in Table (4).

Table 2. Percentages of area cultivated with major field crops in the four studied areas

\begin{tabular}{lcccc}
\hline \multirow{2}{*}{ Crop } & \multicolumn{4}{c}{ Governorate } \\
\cline { 2 - 5 } & Behira & North Sinai & Fayoum & Menia \\
\hline Wheat & 48 & ---- & 28 & 47 \\
Rice & 46 & ---- & ---- & ---- \\
Green fodder & 51 & ---- & 28 & 33 \\
Maize & 48 & ---- & 30 & 39 \\
Onion & ---- & --- & 26 & 28 \\
Tomato & ---- & --- & 30 & 49 \\
Olive & ---- & 50 & ---- & ---- \\
Peach & ---- & 44 & --- & -- \\
\hline
\end{tabular}

Table 3. Least squares means $(\bar{X})$ and standard errors (SE) of production resources in the four studied areas

\begin{tabular}{|c|c|c|c|c|c|c|c|c|c|}
\hline \multirow{2}{*}{ Classification } & \multirow{2}{*}{$\mathbf{N}$} & \multicolumn{4}{|c|}{ Family size (person) } & \multicolumn{2}{|c|}{ Farm size (feddan) } & \multicolumn{2}{|c|}{ Herd size (head) } \\
\hline & & $\bar{X}$ & & SE & $\mathbf{P}$ & SE & $\mathbf{P}$ & SE & $\mathbf{P}$ \\
\hline Overall mean & 151 & 5.2 & \pm & 0.04 & 0.007 & $3.8 \pm 0.17$ & 0.008 & $1.8 \pm 0.002$ & 0.0001 \\
\hline \multicolumn{10}{|l|}{ Governorate } \\
\hline Behira & 30 & $5.5^{\mathrm{ab}}$ & \pm & 0.28 & & $1.9^{\mathrm{a}} \pm 0.93$ & & $1.2^{\mathrm{a}} \pm 0.11$ & \\
\hline North Sinai & 39 & $5.8^{\mathrm{b}}$ & \pm & 0.24 & & $6.1^{\mathrm{b}} \pm 0.81$ & & $1.3^{\mathrm{a}} \pm 0.10$ & \\
\hline Fayoum & 30 & $4.9^{\mathrm{ab}}$ & \pm & 0.28 & & $3.9^{\mathrm{ab}} \pm 0.93$ & & $2.8^{\mathrm{c}} \pm 0.11$ & \\
\hline Menia & 52 & $4.8^{\mathrm{a}}$ & \pm & 0.21 & & $3.3^{\mathrm{ab}} \pm 0.76$ & & $2.1^{\mathrm{b}} \pm 0.09$ & \\
\hline
\end{tabular}

$\mathrm{N}=$ no. of observations, means followed by different letters within the same column are significantly different $(\mathrm{P}<0.01), \mathrm{P}=$ probability of type one error.

Table 4. Distribution the produced milk in the four studied areas

\begin{tabular}{lcccccc}
\hline \multirow{2}{*}{ Governorate } & \multicolumn{3}{c}{ Family consumption (\%) } & \multicolumn{3}{c}{ Market sales (\%) } \\
\cline { 2 - 7 } & Buffalo & Cow & Average & Buffalo & Cow & average \\
\hline Behira & 40 & 45 & 42 & 60 & 55 & 58 \\
North Sinai & ---- & 20 & 20 & --- & 80 & 80 \\
Fayoum & 30 & 23 & 27 & 70 & 77 & 73 \\
Menia & 25 & 35 & 30 & 75 & 65 & 70 \\
\hline Average & 30 & 30 & 30 & 70 & 70 & 70 \\
\hline
\end{tabular}




\section{Crop management practices}

Source of irrigation water is mainly obtained from River Nile. Underground water and rains also represent another source of water for North Sinai governorate. The sprinkling, dripping and soaking techniques of irrigation are the common irrigation systems. Most of farmers used machinery, particularly, in preparing the soil for cultivation. These equipment are owned by farmers or are rented. Most of farmers in the current studied areas utilized chemical fertilizers, in addition to manure produced from their own farms.

\section{Technical coefficients \\ Animal production}

Most of published estimates on productive performance of buffalo and native cows were obtained from state and experimental farms. It is of interest to compare these estimates with those obtained in the present study. Least squares means of productive and reproductive traits (TMY, LP, DMY and $\mathrm{CI}$ ) and standard errors in the four studied governorates for buffalo are presented in Table (5). The overall mean of TMY was estimated as $1720 \mathrm{~kg}$ for buffalo. The estimate of the current study is lower than those reported by Abdel-Aziz and Hamed (1979), $1979 \mathrm{~kg}$ ), Cattle information System/Egypt, CISE (2012, $1851 \mathrm{~kg}$ ) under smallholders, and Ibrahim (2012), $1854 \mathrm{~kg}$ ) and higher than those reported by Mostageer et al. (1981, $1277 \mathrm{~kg}$ ), Nigm et al. (1986), $1246 \mathrm{~kg}$ ), Abdel-Aziz (1993), $1250 \mathrm{~kg}$ ) and Ahmed et al. (1996), $1166 \mathrm{~kg}$ ). Governorate was found to have highly significant effect $(\mathrm{P}<0.001)$ on TMY and contributed $52 \%$ of the total variation. These differences in estimates may be due to different management practices or because of selected buffaloes distributed by CFAWD. Buffaloes raised in Fayoum produced more total milk yield $(2492 \mathrm{~kg})$ compared to those of Behira $(1675 \mathrm{~kg})$ and Menia governorates $(1342 \mathrm{~kg})$, these differences accounted for $32.8 \%$ of Behira governorate and $46.1 \%$ of Menia, these difference may be due to the pioneer role of CFAWD in distributing elite buffaloes in Fayoum governorate in order to increase milk production and improve income of the small farmers.

The least squares overall mean for TMY of cows was estimated as $1303 \mathrm{~kg}$. The estimate of the present study is higher than those reported by Nigm et al. (1986) of $638 \mathrm{~kg}$ and Abdel-Aziz (1993) of 640 $\mathrm{kg}$. Technical coefficients (DMY, LP, TMY and CI) of dairy cows among the studied areas are presented in Table (6). Native cows raised in Fayoum governorate produced the highest total milk yield compared to those in the other three governorates. These differences may be attributed to longer lactation period of cows in Fayoum than cows in Behira, North Sinai and Menia (225 days vs. 168 days, 195 days and 217 days, respectively).

Table 5. Productive and reproductive indicators of buffaloes under the four studied areas

\begin{tabular}{|c|c|c|c|c|c|c|c|c|c|}
\hline \multirow{2}{*}{ Classification } & \multirow{2}{*}{$\mathbf{N}$} & \multicolumn{2}{|c|}{ TMY (kg) } & \multicolumn{2}{|c|}{ LP (day) } & \multicolumn{2}{|c|}{ DMY (kg) } & \multicolumn{2}{|c|}{ CI (day) } \\
\hline & & SE & $\mathbf{P}$ & SE & $\mathbf{P}$ & SE & $\mathbf{P}$ & SE & $\mathbf{P}$ \\
\hline Overall mean & 162 & $1720 \pm 169$ & 0.0001 & $229 \pm 8.5$ & 0.0001 & $7.3 \pm 0.15$ & 0.0001 & $463 \pm 20$ & $\mathrm{NS}$ \\
\hline \multicolumn{10}{|l|}{ Governorate } \\
\hline Behira & 27 & $1675^{a} \pm 225.9$ & & $170^{\mathrm{a}} \pm 11.4$ & & $9.8^{a} \pm 0.94$ & & $460 \pm 23$ & \\
\hline North Sinai & ---- & ---- & & ---- & & ---- & & ---- & \\
\hline Fayoum & 57 & $2492^{c} \pm 137.5$ & & $249^{b} \pm 6.9$ & & $10.0^{\mathrm{a}} \pm 0.57$ & & $470 \pm 18$ & \\
\hline Menia & 78 & $1342^{\mathrm{b}} \pm 142.9$ & & $231^{\mathrm{b}} \pm 7.2$ & & $6.0^{\mathrm{b}} \pm 0.59$ & & $460 \pm 21$ & \\
\hline
\end{tabular}

$\mathrm{N}=$ no. of observations, means followed by different letters within the same column are significantly different $(\mathrm{P}<0.01), \mathrm{P}=$ probability of type one error

Table 6. Productive and reproductive indicators of dairy cows under the four studied areas

\begin{tabular}{|c|c|c|c|c|c|c|c|c|c|c|c|}
\hline \multirow{2}{*}{ Classification } & \multirow{2}{*}{$\mathbf{N}$} & \multicolumn{2}{|c|}{ TMY (kg) } & \multicolumn{2}{|c|}{ LP (day) } & \multicolumn{3}{|c|}{ DMY (kg) } & \multicolumn{3}{|c|}{ CI (day) } \\
\hline & & SE & $\mathbf{P}$ & SE & $\mathbf{P}$ & $X$ & SE & $\mathbf{P}$ & $X$ & SE & $\mathbf{P}$ \\
\hline Overall mean & 272 & $1303 \pm 83.1$ & 0.0001 & $210 \pm 3.3$ & 0.0001 & $6.0 \pm$ & 0.37 & 0.0001 & $459 \pm$ & 10 & 0.02 \\
\hline \multicolumn{12}{|l|}{ Governorate } \\
\hline Behira & 35 & $1485^{\mathrm{a}} \pm 111.3$ & & $168^{a} \pm 4.5$ & & $8.9^{a}=$ & \pm 0.49 & & $380^{\mathrm{a}} \pm$ & \pm 11 & \\
\hline North Sinai & 51 & $1276^{\mathrm{b}} \pm 90.2$ & & $195^{b} \pm 3.6$ & & $6.5^{\mathrm{bc}}$ & \pm 0.40 & & $456^{\mathrm{b}}=$ & \pm 10 & \\
\hline Fayoum & 82 & $1688^{c} \pm 70.7$ & & $225^{c} \pm 2.8$ & & $7.5^{c} \pm$ & \pm 0.31 & & $502^{c} \pm$ & \pm 9 & \\
\hline Menia & 104 & $1249^{b} \pm 60.1$ & & $217^{\mathrm{c}} \pm 2.4$ & & $5.6^{\mathrm{b}} \pm$ & \pm 0.26 & & $498^{b c}$ & \pm 9 & \\
\hline
\end{tabular}

$\mathrm{N}=$ no. of observations, means followed by different letters within the same column are significantly different $(\mathrm{P}<0.01), \mathrm{P}=$ probability of type one error.

\section{Crop production}

The crop yield/feddan is a composite trait resulting from the interaction of natural factors, rotation design, weed control, soil fertility and structure, seedling rate, system of irrigation, cultivation date and timing of each operation. The least squares means and standard errors for crop yield per feddan of the major field crops in the four governorates are presented in Table (7). The overall means of crop yield per feddan were 17.8 ardab for wheat, 13.1 ardab for maize and 22.3 tons for berseem. Governorate showed highly significant effect on crop yield of wheat and berseem among studied areas and contributed $15 \%$ and $7 \%$ of the total variance in the two crops, respectively. 
Table 7. Least squares means (X) and standard errors (SE) for main crops yield per feddan under the four studied areas

\begin{tabular}{|c|c|c|c|c|c|c|}
\hline \multirow{2}{*}{ Classification } & \multicolumn{2}{|c|}{ Wheat (ardab) } & \multicolumn{2}{|c|}{ Maize (ardab) } & \multicolumn{2}{|c|}{ Berseem (ton) } \\
\hline & SE & $\mathbf{P}$ & SE & $\mathbf{P}$ & SE & $\mathbf{P}$ \\
\hline Overall mean & $17.8 \pm 0.80$ & 0.001 & $13.1 \pm 1.31$ & 0.241 & $23.3 \pm 4.8$ & 0.0001 \\
\hline \multicolumn{7}{|l|}{ Governorate } \\
\hline Behira & $15.8^{a} \pm 0.84$ & & $15.7 \pm 2.00$ & & $20^{\mathrm{a}} \pm 4.9$ & \\
\hline North Sinai & ---- & & ---- & & ---- = & \\
\hline Fayoum & $20.0^{\mathrm{b}} \pm 0.79$ & & $13.6 \pm 1.05$ & & $28^{b} \pm 4.7$ & \\
\hline Menia & $17.5^{\mathrm{a}} \pm 0.77$ & & $12.3 \pm 0.87$ & & $22^{\mathrm{a}} \pm 4.7$ & \\
\hline
\end{tabular}

Ardab $=75 \mathrm{~kg}$, means followed by different letters within the same column are significantly different $(\mathrm{P}<0.01), \mathrm{P}=$ probability of type one error.

\section{Farm budget}

The whole farm budget analysis of the four studied governorates, Behira, North Sinai, Fayoum and Menia are illustrated in figures 1, 2, 3 and 4. The results revealed that $24.1 \%, 53.8 \%, 53.4 \%$ and $42.7 \%$ of the annual variable costs are going to the animal production activities, while 75.9, 46.2, 46.6 and $57.3 \%$ are going to the crop activities, in the four studied areas, respectively. Out of animal production variable costs, feeding costs represented about 54\%, $81 \%, 81 \%$ and $75 \%$, respectively. On the other hand, animal production revenues of the studied farming system at Behira, North Sinai, Fayoum and Menia generated $43 \%, 28.5 \%, 60.4 \%$ and $39.2 \%$ of the annual revenues, respectively.

The breakdown of livestock products showed that milk production revenues constituted $38.3 \%, 15.9 \%$, $38 \%$ and $22.9 \%$ of the whole farm gross output, respectively. It seems that farmers of Fayoum and Menia governorates were more interested in raising poultry, since it constituted about $11.3 \%$ and $8 \%$ of the annual farm revenues, respectively. These variations may due to the different objectives, know how of each farmer, herd size and composition.

The breakdown of crop products' results also showed that rice crop is considered the major source of income in Behira and achieved $19.4 \%$ of the whole farm revenues. While in North Sinai, olive is considered the major crop and represented $52.1 \%$ of the whole farm revenues. On the other hand, tomato is considered the major crop in Fayoum and Menia governorates and constituted $10.2 \%$ and $30.4 \%$ of the whole farm revenues, respectively.

\section{Economical efficiency}

Return per unit of limited resources are presented in Table (8). The obtained values of the return per feddan and per AU revealed that Behira farmers beneficiaries utilized their limited production resources more efficient than the other studied governorates since they achieved the highest return per feddan (L.E. 7276). However, Menia farmers achieved the highest return/AU (L.E. 21635). In the same context, overall $\mathrm{B} / \mathrm{C}$ ratio was higher in Behira (3.1) than the others governorates. The current estimate of results are higher than those obtained by Ahmed et al. (2000) of LE 870 and LE 1950, respectively under small-scale farm in South Tahreer Province operated by university graduates. The current results revealed that reward of livestock production activities is profitable under proper management and suitable allocation of the available resources.

Table 8. Economical efficiency of the mixed farming system in the studied governorates in LE

\begin{tabular}{|c|c|c|c|c|}
\hline Criteria & Behira & North Sinai & Fayoum & Menia \\
\hline Gross margin / feddan & 7276 & 1749 & 3245 & 4395 \\
\hline Gross margin / AU & 11520 & 8542 & 4520 & 21635 \\
\hline Overall benefit / cost ratio & 3.1 & 2.0 & 1.4 & 2.1 \\
\hline Livestock benefit / cost ratio & 5.5 & 1.0 & 1.6 & 1.9 \\
\hline Crops benefit / cost ratio & 2.3 & 3.0 & 1.2 & 2.2 \\
\hline
\end{tabular}

\section{CONCLUSION}

Results of the current study revealed that animal production is a profitable activity in the mixed farming system in the studied areas. However, these areas are facing various constraints including high feeding costs, lack of milk cooling chain and milk processing facilities. To achieve sustainable development of the current crop/livestock production system, applicable proposed scenarios can include establishment of infrastructure for milk collection, provision of choppers to chop crop residues to reduce feeding costs and provide farmers with simple equipment for milk processing (separators and churns). Other option may be the replacing of native cows with crossbred ones.

\section{ACKNOWLEDGEMENT}

The author appreciates the Central Fund of Animal Wealth Development (CFAWD) and Cattle Information System/ Egypt (CISE) for providing data.

\section{EFERENCES}

Abdel Aziz, A.S., 1993. Production System In: Animal Protein Food System, increasing efficiency of 
production, processing and marketing. Winrock International Institute for Agricultural Development. Project No. 263-2020, Cairo, Egypt.

Abdel Aziz, A.S. and M.K. Hamed, 1979. Region by season age correction factors for adjusting milk records to mature basis in buffaloes. Egyptian Journal of Animal Production, 119:227

Abdel-Salam, S.A.M., S. Abou-Baker, M.A.M. Ibrahim, R.R. Sadek and A.S. Abdel-Aziz, 2008. Analysis of milk records of buffaloes collected under different production systems. Egyptian J. Anim. Prod., 45 Suppl. Issue, Dec.: 79-83

Ahmed, A.M., Nayera Z. Bedier, M.A.M. Ibrahim and A.S. Abdel-Aziz. 1996. Efficiency of the crop/livestock production system in a reclaimed desert area in Egypt. Egyptian J. Anim. Prod., 33, Suppl. Issue, Nov.: $81-90$.

Ahmed, A.M., S. Abo-Baker, R.R. Sadek and A.S. Abdel-Aziz, 2000. Appraisal of the current crop/livestock production system in a new area operated by university graduate in Egypt. Proc. 3rd all Africa Conf. Anim. Agric. \& 11th Conf. Egyptian Soc. Anim. Prod. Alexandria, Egypt, 6-9 Nov. : 629-633

Barnard, C.S. and J.S. Nix, 1993. Farm Planning and Control, 2nd Edition. Cambridge University Press, Cambridge.

Byerlee, D., M.P. Collinson, R.K. Perrin, D.L. Winkelmann, S. Biggs, E.R. Moscardi, J.C. Martines, L. Harrington and A. Benjamin, 1980. Planning technologies appropriate to farmers, concepts and procedures. CIMMYT, El Batan, Mexico.
CISE, 2012. Cattle Information System/Egypt. Egyptian Buffalo Herdbook, The 4th Edition.

Ibrahim, M.A.M., 2012. Effect of enrollment in milk recording systems on improving milk production of Egyptian buffalo. J. Animal and Poultry Prod., Mansoura Univ., Vol. 3 (1): 39-46.

Nigm, A.A., I. Soliman, M.K. Hamed and A.S. AbdelAziz, 1986. Milk production and reproductive performance of Egyptian cows and buffaloes in small livestock holdings. Proc. 7th Conf. of Anim. Prod., Sept. 16-18, Egyptian Soc. of Anim. Prod., Cairo, Egypt.

Morley, F.H.W., 1982. A system approach to animal production, what is it about ?. Proc. Aust. Soc. Anim. Prod. 9:1.

Mostageer, A., M.A. Morsy and R.R. Sadek, 1981. The production characteristics of a herd of Egyptian buffaloes. Zeitschrift für Tierzüchtung und Züchtungsbiologie 98 (1- 4), 220-236

Nygaard, D.F., 1980. Socioeconomic constraints to the future development of the dryland farming regions of the world. International Congress of Dryland Farming. Aug. 25 to Sept. 5. Adelaide, Australia.

Robert, H., 1982. Characterization of farming systems. Proceedings of A Workshop on Research on CropAnimal Systems. April 4-7. Turrialba, Costa Rica.

SAS, 2001. Procedures Guide, Version 8.2, Statistical Analysis Systems Institute Inc. Cary NC 275118000, USA.

Zandstra, H.G., 1977. Cropping system research for the Asian rice farmer. Symposium on Cropping System Research and Development for the Asian Rice Farmers. IRRI, Los Banos, Philippines. 


\begin{tabular}{|c|c|c|c|c|c|}
\hline \multicolumn{6}{|c|}{$\begin{array}{c}\text { Breakdown of annual variable costs and revenues in LE } \\
\text { of mixed farming system at Behira governorate. }\end{array}$} \\
\hline \multicolumn{3}{|c|}{ Farm size $=1.9$ feddan } & \multicolumn{3}{|c|}{ Herd size $=1.2$ heads } \\
\hline \multicolumn{3}{|c|}{ Variable costs } & \multicolumn{2}{|c|}{\begin{tabular}{ll}
\cline { 2 - 2 } & Revenues \\
\end{tabular}} & \\
\hline \multicolumn{3}{|l|}{$\downarrow$} & \multicolumn{3}{|c|}{$\downarrow$} \\
\hline Animal production & Value & $\%$ & Animal production & Value & $\%$ \\
\hline Labor & 495 & 7.4 & Milk & 7880 & 38.3 \\
\hline Concentrate feed mixture & 330 & 4.9 & Meat & ---- & \\
\hline Green fodder & 395 & 5.9 & Manure & 960 & 4.7 \\
\hline Roughages & 150 & 2.2 & Table eggs & ---- & --- \\
\hline Vet. Care & 250 & 3.7 & & & \\
\hline Total & 1620 & 24.1 & Total & 8840 & 43 \\
\hline Crop production & Value & $\%$ & Crop production & Value & $\%$ \\
\hline Labor & 530 & 7.9 & Wheat & 3670 & 17.9 \\
\hline Machinery & 775 & 11.5 & Berseem & 1870 & 9.1 \\
\hline Chemical fertilizer & 1180 & 17.5 & Maize & 1065 & 5.2 \\
\hline Organic fertilizer & 960 & 14.3 & Darawa & 685 & 3.3 \\
\hline Seeds & 1670 & 24.8 & Rice & 3980 & 19.4 \\
\hline Total & 5115 & 75.9 & Total & 11730 & 57 \\
\hline
\end{tabular}

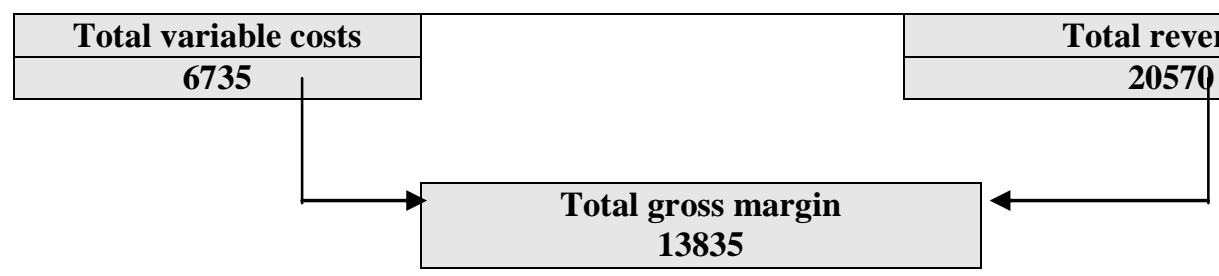




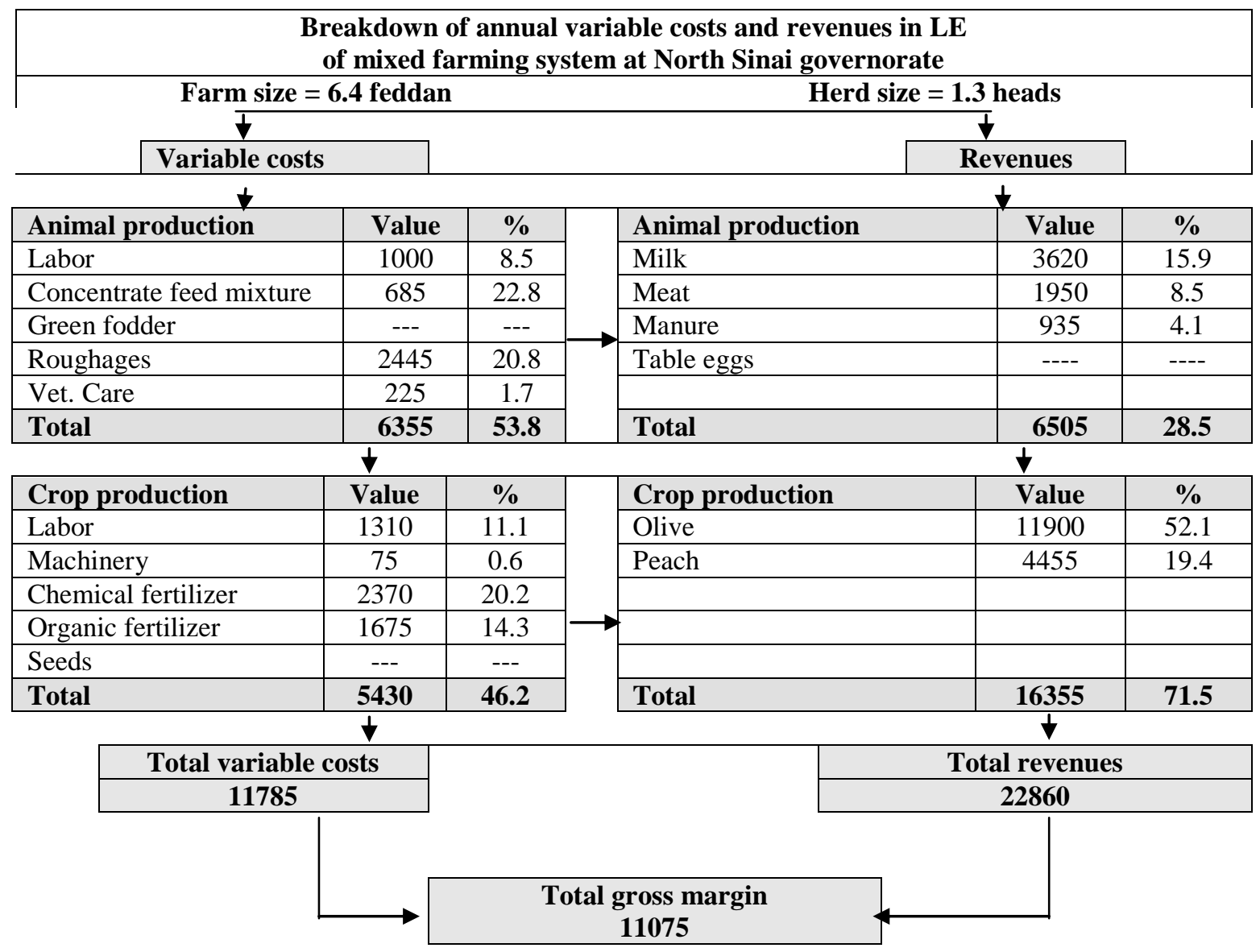




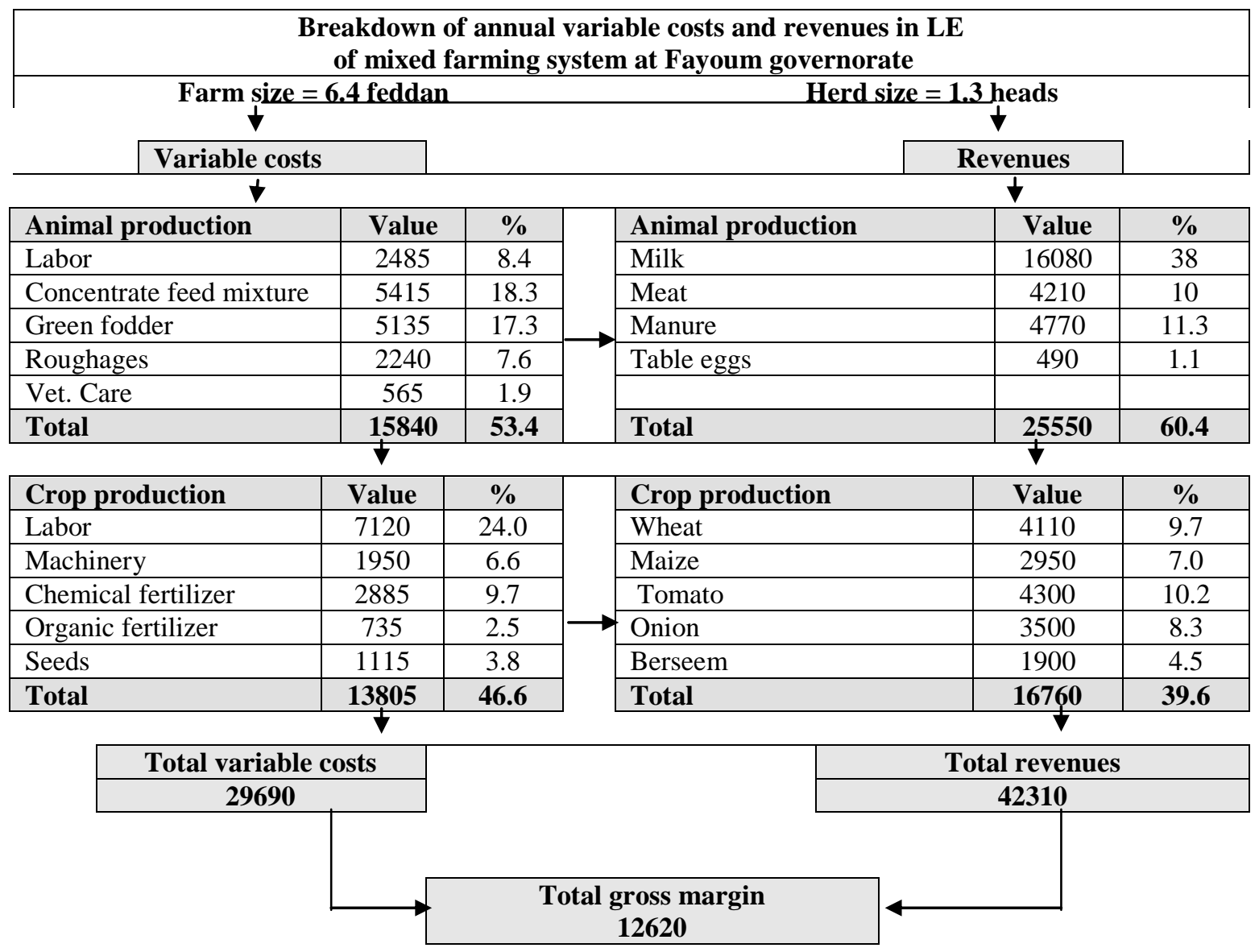




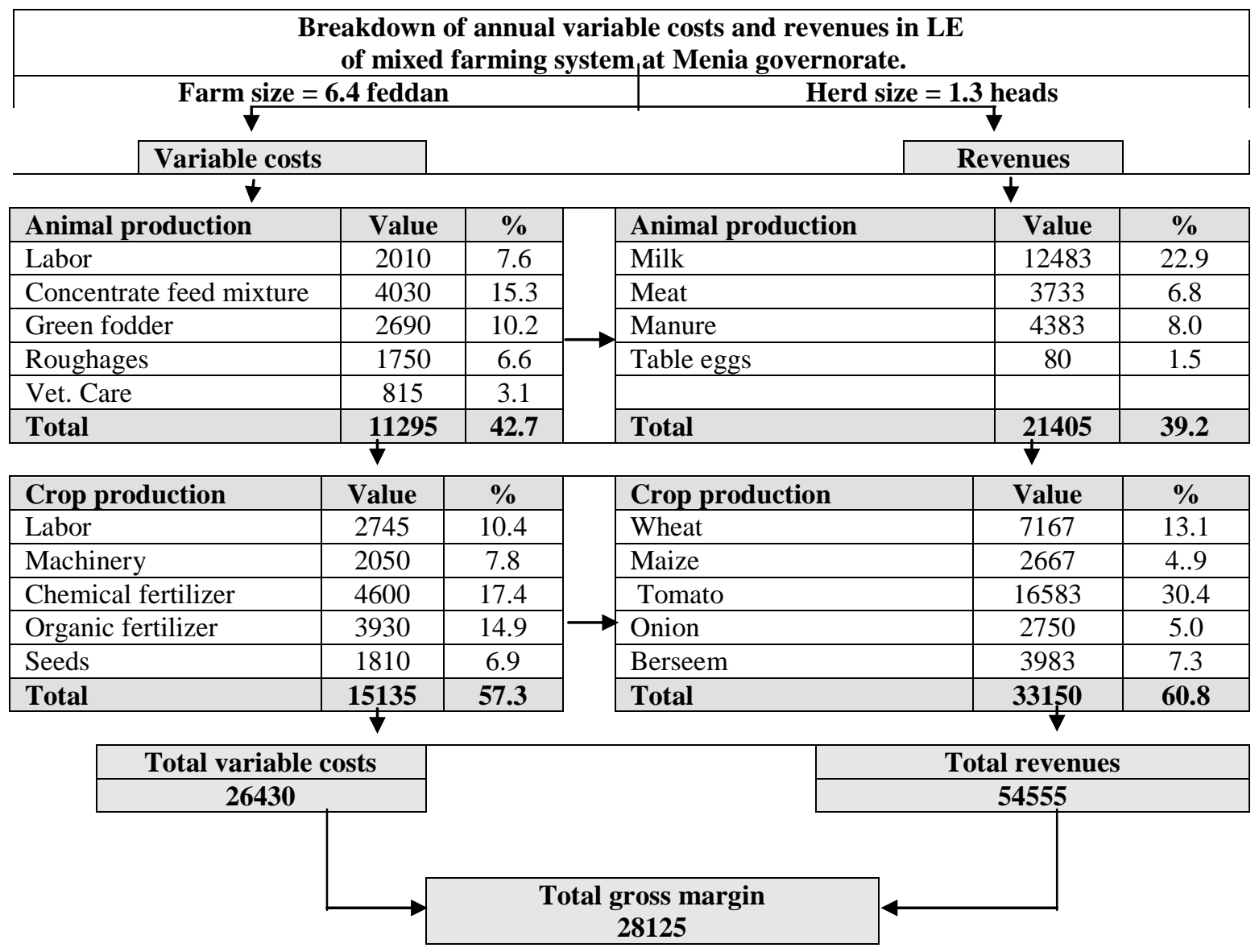


توصيف نظام الإنتاج النباتى/الحيوانى فى المناطق المستصلحة فى مصر ياسر أحمد عبدالعزيز معهج بحوث الإنتاج الحيوانس، وزارة الزراعة، مصر

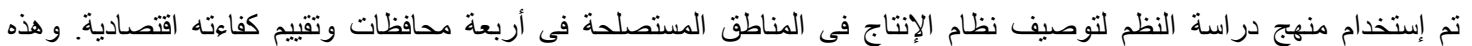

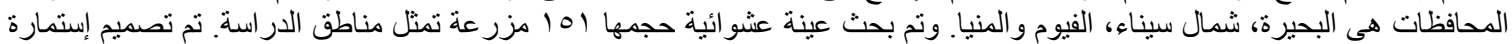

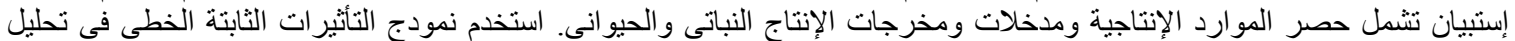

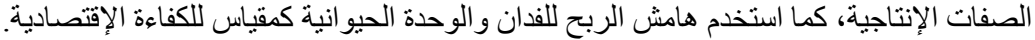

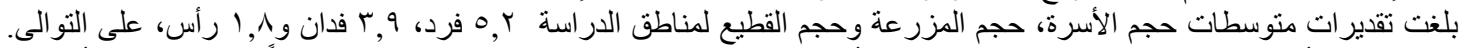

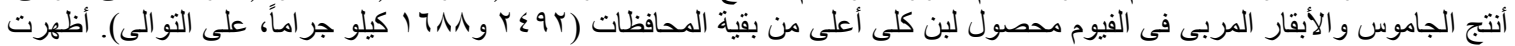

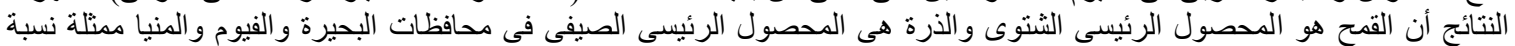

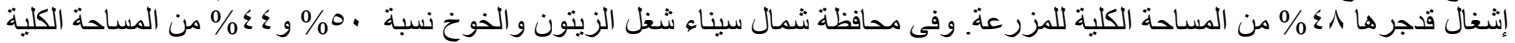

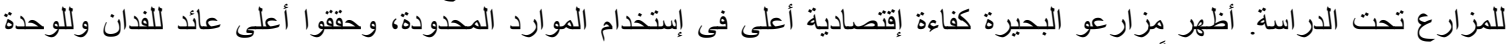

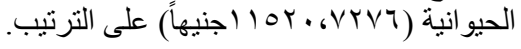

